\author{
Mirna Burić \\ DV Smokvica, Zaprešić \\ Maja Cepanec \\ Sanja Šimleša \\ Sveučiliste u Zagrebu, Edukacijsko-rehabilitacijski \\ fakultet, Odsjek za logopediju
}

\section{Obilježja neverbalne komunikacije djece sa selektivnim mutizmom - nalikuju li onima u poremećaju iz spektra autizma?}

\author{
Characteristics of nonverbal communication in \\ children with selective mutism - do they \\ resemble those seen in autism spectrum \\ disorder?
}

\begin{abstract}
SAŽETAK
Selektivni mutizam (SM) rijedak je anksiozni poremećaj, obilježen odsutnošću govora u socijalnim situacijama u kojima se od osobe očekuje da govori, čak i kada ona može govoriti u drugim situacijama. Cilj ovoga rada bio je: ispitati obilježja neverbalne komunikacije djece predškolske i rane školske dobi koja imaju selektivni mutizam, utvrditi i opisati koja su obilježja zajednička djeci sa selektivnim mutizmom i onoj s poremećajem iz spektra autizma (PSA) u situaciji ispitivanja. Osim toga, cilj rada bio je: odrediti razlikovna obilježja djece sa selektivnim mutizmom i one s poremećajem iz spektra autizma u ispitnoj situaciji, radi dobivanja smjernica za lakši postupak dijagnosticiranja selektivnog mutizma. Obilježja neverbalne komunikacije ispitana su Opservacijskim protokolom za dijagnostiku autizma (ADOS-2; Lord i sur., 2012), a u istraživanju je sudjelovalo sedam djevojčica u dobi od 5 do 10 godina. Rezultati pokazuju kako je većina djece sa selektivnim mutizmom imala minimalan kontakt očima $(57,1 \%)$ te oskudne izraze lica. Djeca su upotrijebila konvencionalne, informativne $\mathrm{i}$ instrumentalne geste prilikom odgovora na pitanja, no opisne geste javile su se u vrlo malom broju. Nadalje, djevojčice su rijetko započinjale socijalne interakcije, davale informacije o sebi ili tražile informacije od ispitivača. Iako su obilježja komunikacije i interakcija djevojčica sa selektivnim mutizmom u ispitnoj situaciji prilično nalikovala obilježjima djece sa PSA-om, postoje ponašanja koja čine razlikovna obilježja navedena dva poremećaja. Odstupanja u neverbalnoj komunikaciji djece sa selektivnim mutizmom prisutna su samo u određenim situacijama. Isto tako, nepostojanje stereotipnih i drugih neuobičajenih ponašanja, upotreba gesta te afektivni socijalni odnosi jasno razlikuju selektivni mutizam i poremećaj iz spektra autizma.
\end{abstract}

\begin{abstract}
Selective mutism (SM) is a rare anxiety disorder characterized by the failure to speak in specific social situations (e.g., at school), despite speaking normally in other situations (e.g., at home). Numerous studies have shown that children with selective mutism, instead of communicating verbally, often use nonverbal behavioral patterns such as head-nodding, pointing, facial expressions, etc. The aim of this study was to investigate the characteristics of nonverbal communication in preschool and younger school-aged children with selective mutism as well as to identify and describe common features of children with selective mutism and children with autism spectrum disorder (ASD) in the assessment environment. In addition, the aim of this study was to determine the distinctive features of children with selective mutism and children with autism spectrum disorder in a socially challenging situation (assessment) in order to obtain guidelines that will help in differential diagnosis. Seven girls with SM aged between 5 and 10 years were examined using Autism Diagnostic Observation Schedule (ADOS-2; Lord et al., 2012). The results showed that most of the children with selective mutism had minimal eye contact $(57,1 \%)$ as well as the lack of facial expressions. Children used conventional, instrumental and informational gestures to answer the questions, but they rarely used descriptive gestures. Furthermore, participants rarely initiated social interactions, offered information about themselves and asked for information. Although girls with SM showed characteristics of communication and interaction similar to those seen in children with autism spectrum disorder, there are behaviors that make up distinctive characteristics of these two disorders. Deficits in nonverbal communication in children with SM are present only in particular settings. In addition, the lack of stereotyped and other abnormal behaviors, use of gestures and affectionate social relationships are characteristics that clearly differentiate selective mutism and autism spectrum disorder.
\end{abstract}

Ključne riječi: selektivni mutizam neverbalna komunikacija - ADOS-2 poremećaj iz spektra autizma

Keywords: selective mutism - nonverbal communication - ADOS-2 autism spectrum disorder 


\section{UVOD}

\section{Obilježja selektivnog mutizma}

Selektivni mutizam (SM) anksiozni je poremećaj, obilježen trajnim izostankom govora u socijalnim situacijama u kojima se od djeteta očekuje da govori (npr. u školi ili dječjem vrtiću), unatoč tome što dijete može govoriti u ostalim situacijama (npr. kod kuće). Djeca sa selektivnim mutizmom govore u svome domu u prisutnosti najbližih članova obitelji, ali ne započinju socijalne interakcije nit odgovaraju kada im se obrate druge osobe (Američka psihijatrijska udruga, 2014). Poremećaj se razvija između 2. i 4. godine, no znakovi mutizma ne moraju biti vidljivi dok dijete ne krene u vrtić ili školu, kada su pred njim povećani socijalni zahtjevi i radni zadaci (traženje pomoći, sudjelovanje u grupnim aktivnostima, čitanje naglas i slično). Selektivni mutizam je relativno rijedak. U Dijagnostičkom statističkom priručniku za mentalne bolesti (DSM-5; Američka psihijatrijska udruga, 2014) navedeno je kako se javlja od 0,03 do $1 \%$ slučajeva, no stupanj prevalencije uvelike ovisi o kronološkoj dobi sudionika, dijagnostičkim kriterijima koji se primjenjuju te uzorku sudionika (klinički ili školski uzorak). Iako je, na osnovi nekih istraživanja, selektivni mutizam jednako zastupljen kod djevojčica dječaka (Vecchio i Kearney, 2007), druga tvrde kako je on češći kod djevojčica, navodeći omjere od 1,5 do 2:1 u korist djevojčica (Black i Uhde, 1995; Kristensen, 2000; Kearney, 2010).

Obilježja zajednička većini djece sa selektivnim mutizmom su: narušena verbalna i neverbalna komunikacija, prosječna ili iznadprosječna inteligencija, osjetljivost, "smrzavanje" i/ili neobični pokreti tijela - stisnutost, napetost gornjeg dijela tijela te napeti izrazi lica kada je dijete anksiozno, slab kontakt očima te odgovaranje latencijom (Kotrba, 2014). Osim toga, djeca sa selektivnim mutizmom mogu pokazivati različita popratna obilježja: pretjeranu sramežljivost, strah od posramljivanja, socijalnu izolaciju i povlačenje, ljepljivost, kompulzivne crte, negativizam, ispade bijesa te blago suprotstavljanje (Američka psihijatrijska udruga, 2014). Budući da rijetko započinju i sudjeluju u interakcijama s nepoznatim ljudima te izbjegavaju bilo kakve aktivnosti koje uključuju govor, djeca sa selektivnim mutizmom imaju značajno manje prilika za usvajanje socijalnih i jezičnih vještina primjerenih dobi, kao i slabija akademska postignuća (Nowakowski i sur., 2009). Primjerice, djeca ne postavljaju pitanja kada nešto ne razumiju, što može rezultirati nedovršenim zadaćama i zaostajanjem u gradivu, učitelji ne mogu procijeniti njihove sposobnosti čitanja i slično. Unatoč toplim i prisnim odnosima $s$ roditeljima, osobito $s$ majkom (Kolvin i Fundudis, 1981), djeca sa SM-om otežano uspostavljaju prijateljstva sa svojim vršnjacima te pokazuju nezrele socijalne vještine (Cline i Baldwin, 2004).

$\mathrm{S}$ obzirom na to da djeca sa SM-om govore samo u određenim situacijama te u većini slučajeva isključivo s članovima uže obitelji, u situacijama kada im se netko izravno obrati ili kada im nešto zatreba, djeca će uglavnom biti sklona upotrijebiti različite oblike neverbalnog ponašanja: pojačani kontakt očima, znatnije oslanjanje na uporabu gesta (kimanje ili odmahivanje glavom, slijeganje ramenima, geta pokazivanja) i izraza lica (Ford, Sladeczek,
Carlson i Kratochwill, 1998; Krysanski, 2003; Moldan, 2005; Omdal i Galloway, 2008; Kearney, 2010). Isto tako, djeca mogu šaptati, pisati poruke, izražavati se na različite kreativne načine - pisanjem slova u zraku (Kearney i Vecchio, 2007). Upravo uspješno prenošenje poruke bez potrebe za verbalnim izražavanjem uvelike pomaže djeci sa selektivnim mutizmom budući da tako ostvaruju svoje potrebe i želje, ne izlažući se situacijama koje su njima vrlo stresne i stvaraju im tjeskobu.

\section{Sličnosti i razlike selektivnog mutizma i poremećaja iz spektra autizma}

Postoje djeca s izraženijim teškoćama mutizma koja u komunikaciji s drugima ne upotrebljavaju ni verbalne ni neverbalne oblike komunikacije (Kotrba, 2014). To znatno otežava njihovo svakodnevno funkcioniranje i dovodi do frustracija roditelja i učitelja, koji se teško nose s takvom situacijom i nastoje pronaći različite načine kako da pomognu djetetu. Djetetova šutnja, rijetko započinjanje interakcija te minimalna neverbalna komunikacija ili njezin izostanak, mogu nalikovati obilježjima djece s poremećajem iz spektra autizma (Kotrba, 2014; Hung, Spencer i Dronamraju, 2012). Poremećaj iz spektra autizma (PSA) neurorazvojni je poremećaj, s trajnim nedostacima u socijalnoj komunikaciji i socijalnoj interakciji u višestrukim kontekstima (nedostaci u socijalno-emocionalnoj uzajamnosti i neverbalnom komunikacijskom ponašanju upotrijebljenom za socijalne interakcije i sl.), te ograničenim, repetitivnim obrascima ponašanja, interesima i aktivnostima (stereotipni ili repetitivni motorički pokreti, inzistiranje na istovjetnosti, jako ograničeni interesi, hiperreaktivnost ili hiporeaktivnost) sa simptomima prisutnima u ranom razvojnom razdoblju (Američka psihijatrijska udruga, 2014). Neverbalno ponašanje djece sa PSA-om varira "od slabo integrirane verbalne $i$ neverbalne komunikacije do abnormalnosti u kontaktu očima i govoru tijela, ili deficita u razumijevanju i korištenju gesta, ili do potpunog pomanjkanja facijalnih izražavanja i neverbalne komunikacije" (Američka psihijatrijska udruga, 2014; str. 50).

Istraživanja pokazuju kako su neka od obilježja djece sa PSA-om pronađena i kod djece sa SM-om kada se nađu u situacijama izvan vlastitoga doma, pa djeca sa SM-om mogu imati oskudniji kontakt očima, rijetko započinjati i slabije sudjelovati u socijalnim interakcijama, ponekad ne upotrebljavati ni verbalna ni neverbalna sredstva $u$ komunikaciji (Moldan, 2005; Marc i Crundwell, 2006; Bork i Harwood, 2010; Kotrba, 2014). Osim toga, Cline i Baldwin (2004) navode kako su zajednička obilježja ova dva poremećaja socijalna anksioznost i strah od nepoznatog, te upozoravaju kako djeca sa SM-om mogu biti pogrešno dijagnosticirana kao djeca s Aspergerovim sindromom (danas dio poremećaja iz spektra autizma).

Unatoč sličnostima koje se mogu javiti promatrajući ponašanja djece sa selektivnim mutizmom i djece $s$ poremećajem iz spektra autizma u ispitnoj situaciji, postoje obilježja koja ih jasno razlikuju. Kotrba (2014) objašnjava kako su obilježja koja nalikuju ponašanju djece sa PSA-om kod djece sa selektivnim mutizmom prisutna u određenim situacijama (primjerice, kada se djeca osjećaju nelagodno ili anksiozno), dok su u djece s poremećajem iz spektra autizma navedena obilježja vidljiva u svim situacijama, bez obzira je li 
to "sigurno" ili ugodno okruženje - vlastiti dom ili, primjerice, školsko okruženje. Korištenje neverbalne komunikacije kod dijela djece sa SM-om, odsutnost stereotipnih ponašanja te nepostojanje ranih razvojnih odstupanja u djece sa selektivnim mutizmom, također razlikuju ova dva poremećaja (Američka psihijatrijska udruga, 2014).

Kao što je navedeno, djeca sa selektivnim mutizmom često $\mathrm{u}$ interakcijama s drugim ljudima upotrebljavaju neverbalne oblike ponašanja. Stručnjaci bi se, stoga - osim prikupljanja osnovnih informacija koje se tiču djetetovih govornih navika, početka mutizma, obiteljskih odnosa, postojanja SM-a kod bliskih rođaka i slično - tijekom procjene trebali usmjeriti i na to kako se dijete neverbalno izražava, koristi li različita neverbalna ponašanja ovisno o situaciji u kojoj se nalazi te ljudima s kojima je u interakciji. Time će izbjeći donošenje pogrešne dijagnoze koja može imati značajne implikacije na djetetov razvoj. Informacije prikupljene tijekom procjene osigurat će vrijedne podatke za planiranje terapije, te će biti posebno važne na početku terapijskih postupaka kada se djetetu dopušta upotreba neverbalnih ponašanja - kimanje ili odmahivanje glavom, pokazivanje, mrmljanje i slično - a kojima se, kako terapija odmiče, pridaje sve manje pažnje te se dijete sustavno potiče na govor (Kearney i Vecchio, 2006).

Neverbalna komunikacija ima važnu ulogu u životu djeteta sa selektivnim mutizmom, često je jedini način na koji ono komunicira s ostatkom svijeta. Usprkos tome, nedovoljno je literature o ovom obliku komunikacije djece sa SM-om, a istraživanja o tome gotovo i nema. Istraživanja neverbalne komunikacije kod osoba s poremećajem iz spektra autizma, međutim, puno su češća. Neverbalna komunikacija općenito je zanemareno područje, ne samo kod djece sa selektivnim mutizmom, već i u djece s drugim jezičnim, govornim i komunikacijskim poremećajima. Naime, i stručnjaci i roditelji prvenstveno se usredotočuju na razvoj verbalne komunikacije. Verbalna komunikacija iznimno je važna u životu svakog pojedinca, no ne smije se zanemariti uloga neverbalne komunikacije koja nam može pomoći u razumijevanju poruka, ali i kao kompenzacijsko sredstvo u slučajevima narušene verbalne komunikacije.

Cilj ovoga rada je: ispitati obilježja neverbalne komunikacije kod djece predškolske i rane školske dobi koja imaju selektivni mutizam, utvrditi i opisati koja su obilježja zajednička djeci sa selektivnim mutizmom i onoj s poremećajem iz spektra autizma u situacijama u kojima se očituje selektivni mutizam (situacija ispitivanja). Osim toga, cilj ovoga rada je: odrediti razlikovna obilježja djece sa SMom i one sa PSA-om u ispitnoj situaciji, radi boljeg razumijevanja komunikacijskih obilježja djece sa SM-om.

\section{METODE}

\section{Sudionici}

$\mathrm{U}$ istraživanju je sudjelovalo sedmero djece, ženskog spola, u dobi od 5,3 do 9,6 godina (prosječna dob bila je 7,5 godina). Četiri djevojčice bile su polaznice osnovne škole, dok su tri djevojčice uključene u redovne vrtićke skupine. Zbog rijetke pojave selektivnog mutizma, uzorak sudionika je prigodan, a djeca koja su sudjelovala u istraživanju morala su ispuniti dijagnostičke kriterije selektivnog mutizma prema DSM-u-5 te imati između 5 i 10 godina. Također, prije svakog ispitivanja zatražen je pisani pristanak roditelja na sudjelovanje u istraživanju.

\section{Mjerni instrument}

Za potrebe ovoga rada korišteno je hrvatsko izdanje Opservacijskog protokola za dijagnostiku autizma (Lord, Gotham i Guthrie, 2017, uz urednice hrvatske verzije Maju Cepanec i Sanju Šimlešu) (ADOS-2), koji omogućava standardiziranu procjenu obilježja komunikacije, socijalne interakcije, igre te repetitivnih i stereotipnih ponašanja. ADOS-2 protokol sastoji se od ukupno pet modula, a odabir modula ovisi o razini jezične proizvodnje te kronološkoj dobi djeteta ili osobe koja se procjenjuje. U ovome je istraživanju primijenjen Modul 3 navedenog protokola, namijenjen ispitivanju djece $\mathrm{i}$ adolescenata u rasponu od kasnije vrtićke dobi do 15 . godine života koji sustavno proizvode povezane višečlane iskaze. Modul 3 sastoji se od ukupno četrnaest strukturiranih i polustrukturiranih aktivnosti (slaganje slagalice, čitanje slikovnice, opisivanje slike, prepričavanje prema slikovnom predlošku i slično), koje od djeteta traže da stupi u komunikaciju i interakciju s ispitivačem. Iako naizgled prirodne, ove aktivnosti omogućuju standardizirano opažanje socijalnog i komunikacijskog ponašanja sudionika.

Nakon ispitivanja slijedi dodjeljivanje kodova ( 0,1 i 2$)$ koji bi trebali biti temeljeni na ponašanju djeteta tijekom cijele primjene protokola ADOS-2. Kod 0 označava ponašanja koja se očekuju od djeteta na toj jezičnoj razini, kod 1 ponašanja koja blaže odstupaju od očekivanoga, dok kod 2 označava odsutnost ili izražene teškoće u promatranome području.

\section{Način provođenja istraživanja}

Kako bi ispitivanje prošlo u što ugodnijoj atmosferi te djevojčice ne bi osjetile preveliku nelagodu, sram i/ili tjeskobu, ispitivač je tijekom cijele procjene davao dodatne komentare, hvalio izvedbe svake djevojčice i motivirao ih tijekom rješavanja zadataka. Isto tako, ispitivač je po potrebi ponekad prilagodio neki zadatak ili skratio vrijeme čekanja na odgovor ili reakciju sudionika. Primjerice, ako je dijete na početku nekog zadatka bilo suzdržano ili sramežljivo, ispitivač je davao više komentara nego što je navedeno u uputama za provedbu protokola ADOS-2, kako bi njihova komunikacija djelovala prirodno i spontano. Ponekad se radi izbjegavanja neugodne tišine jer dijete nije riješilo zadatak - vrlo brzo krenulo na novi zadatak kako se dijete ne bi osjećalo frustrirano ili odbilo dalje surađivati. Odmah nakon ispitivanja ispitivač je kodirao ponašanja uočena $i$ zabilježena tijekom cijele provedbe protokola ADOS-2.

\section{REZULTATI I RASPRAVA}

Svi su rezultati predstavljeni dodijeljenim oznakama/kodovima koji pokazuju u kojoj mjeri se opaženo ponašanje smatra očekivanim/tipičnim (kod 0), odnosno 
postoje li blaga odstupanja (kod 1) ili značajna odstupanja $(\operatorname{kod} 2)$ od očekivanog.

\section{Neverbalna komunikacija}

Rezultati koji opisuju obilježja neverbalne komunikacije predstavljeni su u tablici 1 .

Tablica 1. Deskriptivni pokazatelji dodijeljenih kodova na česticama koje opisuju obilježja neverbalne komunikacije

\begin{tabular}{|l|c|c|c|c|c|c|c|c|}
\hline \multirow{2}{*}{ Čestica } & \multicolumn{2}{|c|}{$\begin{array}{c}\text { Kodovi } \\
(\mathbf{N})\end{array}$} & \multicolumn{4}{|c|}{ Kodovi } & \multirow{2}{*}{ M } & \multirow{2}{*}{ SD } \\
\cline { 2 - 7 } & $\mathbf{0}$ & $\mathbf{1}$ & $\mathbf{2}$ & $\mathbf{0}$ & $\mathbf{1}$ & $\mathbf{2}$ & & \\
\hline $\begin{array}{l}\text { Kontakt } \\
\text { očima }\end{array}$ & 3 & 0 & 4 & 42,9 & 0 & 57,1 & 1,14 & 1,07 \\
\hline $\begin{array}{l}\text { Izrazi lica } \\
\text { upućenih } \\
\text { ispitivaču }\end{array}$ & 2 & 4 & 1 & 28,6 & 57,1 & 14,3 & 0,86 & 0,69 \\
\hline $\begin{array}{l}\text { Uporaba } \\
\text { gesta }\end{array}$ & 1 & 1 & 5 & 14,3 & 14,3 & 71,4 & 1,57 & 0,79 \\
\hline
\end{tabular}

Legenda: $\mathrm{M}=$ središnja vrijednost; $\mathrm{SD}=$ standardna devijacija

\section{Kontakt očima}

Četiri djevojčice $(57,1 \%)$ sa selektivnim mutizmom izbjegavale su kontakt očima ili ga minimalno koristile, dok su tri djevojčice $(42,9 \%)$ imale primjeren kontakt očima tijekom cijele procjene. Budući da su se djevojčice nalazile u ispitnoj situaciji i s nepoznatim ispitivačem, očekivalo se kako će u većini slučajeva kontakt očima biti najoskudniji na početku procjene, no pokazalo se kako su samo dvije djevojčice izbjegavale kontakt očima na početku procjene. Ostalih pet djevojčica su ili imale primjeren kontakt očima ili je njihov kontakt očima bio nedosljedan tijekom cijele procjene. Upotrebljavaju li djevojčice kontakt očima i u koje svrhe, moglo se vidjeti već u prvome zadatku ADOS-2 protokola, unutar kojega se očekuje da djevojčice od ispitivača zatraže dodatne slagalice. Samo je jedna djevojčica u tome zadatku uspostavila kontakt očima s ispitivačem i verbalnim putem zatražila ostale dijelove slagalice.

Neprimjeren te slabo moduliran kontakt očima, zabilježen u nešto više od polovice sudionica $(57,1 \%), \mathrm{u}$ skladu je s brojnim istraživanjima koja pokazuju kako djeca sa selektivnim mutizmom izbjegavaju ili imaju minimalan kontakt očima (Moldan, 2005; Marc i Crundwell, 2006, Bork i Harwood, 2010; Kotrba, 2014). Bork i Harwood (2010) smatraju kako izbjegavanje kontakta očima te šutnja u situacijama kada im se netko izravno obrati, omogućuju djeci sa selektivnim mutizmom privremeno olakšanje, pa se tako ponašaju i kada se nađu u sličnim situacijama. Moldan (2005) naglašava kako dijete "praveći se nevidljivim", tj. izbjegavajući kontakt očima te šuteći, svojim neverbalnim ponašanjem poručuje odrasloj osobi kako se osjeća tjeskobno, neugodno te želi biti samo ili barem ne želi da mu se netko izravno obraća. Međutim, znakovi koje dijete pokazuje, odrasle osobe često ignoriraju i nastavljaju djetetu postavljati sve više pitanja aludirajući na djetetovu šutnju (primjerice, "Zašto mi ne odgovaraš kada ti se obraćam?"), dodatno pogoršavajući djetetu ionako stresnu situaciju.

\section{Irrazi lica upuceni ispitivačn}

Djevojčice sa selektivnim mutizmom najčešće su usmjeravale izraze lica koji su pokazivali emocionalne krajnosti, a kod gotovo svih djevojčica izraz lica većinu vremena bio je neutralan. Kod većine djevojčica izraz lica je ocijenjen neprimjerenim, odnosno u četiri djevojčice procijenjen je blago odstupajućim, a kod jedne značajno odstupajućim.

Izrazi lica su vrlo važni u međuljudskim interakcijama. Istraživanja pokazuju da smo tijekom komunikacije s drugom osobom gotovo neprestano usmjereni na njezino lice. Gullberg i Holmqvist (2006) navode da su sudionici njihovog istraživanja tijekom socijalnih interakcija 91-96\% vremena proveli gledajući lice druge osobe, u usporedbi s 0,2-0,5\% vremena koje su proveli promatrajući geste koje je imala druga osoba. Neprimjerenost izraza lica primijećena kod djevojčica sa selektivnim mutizmom može značajno utjecati na samu komunikaciju, pokazalo se da izrazi lica koji narušavaju socijalnu interakciju nisu u skladu s njome, teže se interpretiraju ili su dvosmisleni, ometaju učinkovitu komunikaciju (Gordon i sur., 2014).

Mnoga su istraživanja pokazala kako djeca sa selektivnim mutizmom često umjesto verbalne komunikacije upotrebljavaju geste i izraze lica (Ford i sur., 1998; Krysanski, 2003; Marc i Crundwell, 2006; Schwartz, Freedy i Sheridan, 2006; Kearney i Vecchio, 2007; Omdal i Galloway, 2008; Mulligan, Hale i Shipon-Blum, 2015). No, u našem su istraživanju samo dvije djevojčice $(28,6 \%)$ usmjeravale primjerene izraze lica kako bi komunicirale afektivna (uživanje, nezadovoljstvo) ili spoznajna (zbunjenost, nepovjerenje) stanja. Četiri djevojčice $(57,1 \%)$ usmjeravale su ispitivaču samo izraze lica koji su pokazivali emocionalne krajnosti, dok jedna djevojčica (14,3\%) nije usmjeravala primjerene izraze lica ispitivaču. Dakle, čak pet djevojčica $(71,4 \%)$ pokazalo je odstupajuća ponašanja na ovoj čestici, što je velik postotak u odnosu na istraživanje Kljunić, Cepanec i Šimleše (2016), koje su na uzorku od 60 djece tipičnih 6-godišnjaka pronašle kako $85 \%$ njih usmjerava ispitivaču širok raspon primjerenih izraza lica.

\section{Uporaba gesta}

Većina djevojčica sa selektivnim mutizmom (71,4\%) postigla je kod 2 na čestici kojom se procjenjuje upotreba gesta (ukazuje na odstupanja od očekivanog), što znači da je bilo nešto spontane upotrebe informativnih, konvencionalnih ili instrumentalnih gesta, no opisnih najčešće nije bilo ili su se rijetko pojavljivale.

Naglašavamo, procjena uporabe gesta u protokolu ADOS-2 u velikoj mjeri određena je spontanom pojavom opisnih gesta (nužno za dodjelu koda 0), uz bitno manju ulogu konvencionalnih, instrumentalnih ili informativnih gesta. Samo je jedna djevojčica spontano upotrijebila nekoliko opisnih gesta i samo je njoj dodijeljen kod 0 .

Većini djevojčica $(71,4 \%$ za korištenje gesta dodijeljen je kod 2 koji označava postojanje odstupanja u promatranom ponašanju, no ovaj kod ne odražava činjenicu da su djevojčice tijekom interakcije $s$ ispitivačem zapravo često spontano upotrebljavale konvencionalne, instrumentalne ili informativne geste. Kada se promatra komunikacijska svrha gesta, djevojčice su najviše upotreblja- 
vale geste kako bi odgovorile na ispitivačeva pitanja (kimanje ili odmahivanje glavom, slijeganje ramenima), često ne uspostavljajući kontakt očima, dok su vrlo rijetko koristile geste kako bi, primjerice, dobile neki predmet ili započele komunikaciju. Zaključno, česta upotreba gesta (posebno instrumentalnih gesta, kao što su slijeganje ramenima, odmahivanje i kimanje glavom) omogućila je djevojčicama uspješno prenošenje poruka bez mnogo verbalne komunikacije.

\section{Recipročna socijalna interakcija}

Iz tablice 2, u kojoj su prikazani ukupan broj i postotak dodijeljenih kodova na česticama recipročne socijalne interakcije, vidljivo je da su djevojčice pokazivale malo ili nimalo zadovoljstva tijekom cijele procjene. Isto tako, djevojčice sa selektivnim mutizmom vrlo su rijetko započinjale interakciju s ispitivačem (6 djevojčica ili 85,7 \% postiglo je kod 2, što znači da djevojčicama nije bilo bitno posvećuje li im ispitivač pažnju ili ne, te su započinjale samo interakcije koje su bile vezane uz predmet interesa ili traženje pomoći).

U većini slučajeva $(71,4 \%)$ komunikacija između ispitivača i djevojčice odnosila se samo na izmjenu pitanja i odgovora (bez vođena razgovora i dodatnih komentara), reakcija djevojčica na njihovo uključivanje u interakciju bila je minimalna ili je nije bilo, a tijekom gotovo svih procjena ispitivač se osjećao blago neugodno te se dosljedno prilagođavao situacijama, reakcijama i odgovorima sudionica, čak i više nego što je propisano u uputama za provođenje protokola ADOS-2.

Rezultati deskriptivne statistike (tablica 2) pokazuju kako se prosječan rezultat $(M=1,71)$ na čestici "Količina započinjanja socijalnih interakcija" kreće prema atipičnom ponašanju (kodirano s 2), što znači da većina djevojčica uopće nije započinjala interakcije te im se ponašanje neznatno mijenjalo u odnosu na to obraća li ispitivač pažnju na njih ili ne.

Sto se tiče socijalnih reakcija djevojčica tijekom procjene, pokazano je kako je pet djevojčica $(71,4 \%)$ minimalno ili uopće nije reagiralo na pokušaje ispitivača da ih uključi u interakciju. Jedna je djevojčica primjereno reagirala na sve pokušaje da ju se uključi u interakcije, dok je jedna djevojčica reagirala na uključenja u interakciju, ali su te reakcije bile ograničene i neobične. Tijekom cijele ADOS-2 procjene zabilježeno je vrlo malo recipročnosti tijekom socijalnih interakcija te spontanog komunikacijskog govora, odnosno većina komunikacije predstavljala je odgovore na pitanja ili je bila povezana sa specifičnim interesima. Većina djevojčica $(71,4 \%)$ na čestici “Cjelokupna kvaliteta odnosa" postigla je kod 2, znači da je velik broj interakcija između djevojčica $\mathrm{i}$ ispitivača bio jednostran ili neuobičajen, ispitivač se dosljedno trebao prilagođavati situacijama i odgovorima sudionica, a procjene su nerijetko bile neugodne s obzirom na pasivnost te minimalne reakcije sudionica na ispitivača.

Djevojčice sa selektivnim mutizmom vrlo su rijetko usmjeravale zadovoljstvo tijekom rješavanja zadataka te razgovora s ispitivačem. Čak 6 djevojčica ili 85,7 \% postiglo je kod 2 na čestici "Dijeljenje uživanja u interakciji”, znači da su pokazivale vrlo malo ili nimalo zadovoljstva tijekom procjene, a samo je jedna djevojčica $(14,3 \%)$ pokazala jasno zadovoljstvo primjereno kontekstu. Visok postotak djece koja su ostvarila kod 2 nije iznenađujući s obzirom na specifičnosti selektivnog mutizma i činjenicu da ADOS-2 protokol zahtijeva od sudionika da pokaže jasno zadovoljstvo ispitivaču (većina djevojčica sa SM-om bila je u interakciji s ispitivačem ili reagirala na njega, što nije bilo dovoljno da bi se procijenilo uživanje).

Tablica 2. Deskriptivni pokazatelji dodijeljenih kodova na česticama koje opisuju obilježja socijalne interakcije

\begin{tabular}{|l|c|c|c|c|c|c|c|c|}
\hline \multirow{2}{*}{ Čestica } & \multicolumn{2}{|c|}{$\begin{array}{c}\text { Kodovi } \\
\text { (N) }\end{array}$} & \multicolumn{4}{c|}{$\begin{array}{c}\text { Kodovi } \\
\text { (\%) }\end{array}$} & \multirow{2}{*}{ M } & SD \\
\cline { 2 - 7 } & $\mathbf{0}$ & $\mathbf{1}$ & $\mathbf{2}$ & $\mathbf{0}$ & $\mathbf{1}$ & $\mathbf{2}$ & \\
\hline $\begin{array}{l}\text { Dijeljenje } \\
\text { uživanja u } \\
\text { interakciji }\end{array}$ & 1 & 0 & 6 & 14,3 & 0 & 85,7 & 1,71 & 0,76 \\
\hline $\begin{array}{l}\text { Kvaliteta } \\
\text { započinjanja } \\
\text { socijalnih } \\
\text { interakcija }\end{array}$ & 1 & 1 & 5 & 14,3 & 14,3 & 71,4 & 1,57 & 0,79 \\
\hline $\begin{array}{l}\text { Količina } \\
\text { započinjanja } \\
\text { socijalnih } \\
\text { interakcija }\end{array}$ & 1 & 0 & 6 & 14,3 & 0 & 85,7 & 1,71 & 0,76 \\
\hline $\begin{array}{l}\text { Kvaliteta } \\
\text { socijalnih } \\
\text { odgovora }\end{array}$ & 1 & 1 & 5 & 14,3 & 14,3 & 71,4 & 1,57 & 0,79 \\
\hline $\begin{array}{l}\text { Količina } \\
\text { recipročne } \\
\text { socijalne } \\
\text { komunika- } \\
\text { cije }\end{array}$ & 1 & 1 & 5 & 14,3 & 14,3 & 71,4 & 1,57 & 0,79 \\
\hline $\begin{array}{l}\text { Cjelokupna } \\
\text { kvaliteta } \\
\text { uspostavlje- } \\
\text { nog odnosa }\end{array}$ & 1 & 1 & 5 & 14,3 & 14,3 & 71,4 & 1,57 & 0,79 \\
\hline
\end{tabular}

Legenda: $\mathrm{M}=$ središnja vrijednost; $\mathrm{SD}=$ standardna devijacija

\section{Pragmatika}

U tablici 3 prikazani su ukupan broj i postotak dodijeljenih kodova na česticama koje se tiču pragmatičkih sposobnosti. Pri analizi navedenih komunikacijskih ponašanja valja imati na umu da se ove komunikacijske funkcije kod djece u dobi od 5 do 10 godina primarno ostvaruju govorom, premda ih je moguće ostvariti i neverbalnim sredstvima. Djevojčice sa selektivnim mutizmom tijekom procjene iznosile su vrlo malo osobnih informacija (6 djevojčica ili 85,7 \%), nisu izvještavale o svojim mislima, osjećajima i iskustvima te su se rijetko ili se uopće nisu raspitivale za ispitivačeve misli, osjećaje ili iskustva $(100 \%)$. Većina djevojčica $(85,7 \%)$ nije samostalno prepričala niti rutinski niti nerutinski događaj, dok su dvije djevojčice prepričale događaje uz potpitanja.

Kotrba (2014) navodi kako djeca sa selektivnim mutizmom, s obzirom na rijetko sudjelovanje u socijalnim interakcijama, mogu imati teškoća u pragmatici, sposobnosti prikladne upotrebe jezika u socijalne i komunikacijske svrhe (pozdravljanje, započinjanje i održavanje razgovora i sl.). U našem istraživanju, djevojčice sa selektivnim mutizmom su vrlo rijetko tijekom procjene davale informacije koje su ispitivaču bile nepoznate (čak šest djevojčica ili 85,7 \% 
rijetko ili nikad nisu podijelile nove informacije s ispitivačem). Iako je svih sedam djevojčica (100\%) postiglo kod 2 na stavci "Traženje informacija", znači da su se rijetko ili se nikad nisu raspitivale o ispitivačevim mislima, osjećajima ili doživljajima, među njima su ipak postojale male varijacije. Naime, dvije su djevojčice primjereno odgovarale na ispitivačeve komentare o svojim mislima $i$ osjećajima, ali se o njima nisu spontano raspitivale.

Tablica 3. Deskriptivni pokazatelji dodijeljenih kodova na česticama koje opisuju obilježja pragmatike

\begin{tabular}{|c|c|c|c|c|c|c|c|c|}
\hline \multirow{2}{*}{ Čestica } & \multicolumn{3}{|c|}{$\begin{array}{l}\text { Kodovi } \\
(\mathbf{N})\end{array}$} & \multicolumn{3}{|c|}{$\begin{array}{c}\text { Kodovi } \\
(\%)\end{array}$} & \multirow[t]{2}{*}{$\mathbf{M}$} & \multirow[t]{2}{*}{ SD } \\
\hline & 0 & 1 & 2 & 0 & 1 & 2 & & \\
\hline $\begin{array}{l}\text { Davanje } \\
\text { informacija }\end{array}$ & 1 & 0 & 6 & 14,3 & 0 & 85,7 & 1,71 & 0,76 \\
\hline $\begin{array}{l}\text { Traženje } \\
\text { informacija }\end{array}$ & 0 & 0 & 7 & 0 & 0 & 100 & 2 & 0,00 \\
\hline $\begin{array}{l}\text { Prepričavanj } \\
\text { e događaja }\end{array}$ & 1 & 0 & 6 & 14,3 & 0 & 85,7 & 1,71 & 0,76 \\
\hline $\begin{array}{l}\text { Komentiranje } \\
\text { tuđih } \\
\text { emocija }\end{array}$ & 0 & 2 & 5 & 0 & 28,6 & 71,4 & 1,71 & 0,49 \\
\hline
\end{tabular}

Legenda: $\mathrm{M}=$ središnja vrijednost; $\mathrm{SD}=$ standardna devijacija

Opisivanje događaja ili prepričavanje priče korisni su pokazatelji pragmatičkih sposobnosti djeteta $\mathrm{i}$ često su dio jezičnih procjena. Djevojčice sa selektivnim mutizmom, u zadatku u kojem su trebale prepričati rutinski i/ili nerutinski događaj, najčešće nisu željele ispričati niti jedan događaj, čak i uz posebne poticaje ispitivača. Stoga je ova sposobnost mogla biti procijenjena samo kod jedne djevojčice (14,3\%), koja je dovoljno detaljno prepričala oba događaja bez posebnih poticaja od ispitivača. Istraživanje McInnes i suradnika (2004) o narativnim sposobnostima sedmero djece sa selektivnim mutizmom i sedmero djece sa socijalnom fobijom kronološke dobi od 7 do 14 godina, pokazalo je kako su djeca sa selektivnim mutizmom, unatoč tome što su imala uredne receptivne jezične sposobnosti i neverbalnu inteligenciju, u odnosu na djecu sa socijalnom fobijom proizvodila kraće, jezično jednostavnije priče s manje detalja, bez obzira na kontekst u kojemu su prepričavala priču.

Rezultati deskriptivne statistike (tablica 3), također pokazuju kako se na svim česticama koje se odnose na pragmatičke sposobnosti djevojčica sa SM-om prosječan rezultat $(M=1,71$ i $M=2)$ kreće prema atipičnom ponašanju, no ove podatke valja tumačiti s oprezom budući da je i kod djece urednog razvoja u ispitnoj situaciji primijećeno rijetko spontano davanje i traženje informacija (Kljunić i sur., 2016).

\section{Stereotipna ponašanja i ograničeni interesi}

Ukupan broj i postotak dodijeljenih kodova na česticama koje se odnose na stereotipna i ostala neuobičajena ponašanja prikazani su u tablici 4. Podaci vrlo jasno prikazuju kako stereotipna ponašanja, neobični senzorički interesi te kompulzivne radnje - koje su vrlo često prisutne kod djece i osoba s poremećajem iz spektra autizma - nisu viđene niti kod jednog sudionika ovoga istraživanja (svim djevojčicama dodijeljen je kod 0 za sve čestice koje se odnose na stereotipna ponašanja).

Tablica 4. Deskriptivni pokazatelji dodijeljenih kodova na česticama koje opisuju stereotipna i ostala neuobičajena ponašanja

\begin{tabular}{|l|c|c|c|c|c|c|c|c|}
\hline \multirow{2}{*}{ Čestica } & \multicolumn{3}{|c|}{$\begin{array}{c}\text { Kodovi } \\
\text { (N) }\end{array}$} & \multicolumn{3}{c|}{$\begin{array}{c}\text { Kodovi } \\
\text { (\%) }\end{array}$} & \multirow{2}{*}{ M } & SD \\
\cline { 2 - 7 } & $\mathbf{0}$ & $\mathbf{1}$ & $\mathbf{2}$ & $\mathbf{0}$ & $\mathbf{1}$ & $\mathbf{2}$ & & \\
\hline $\begin{array}{l}\text { Neuobičajen } \\
\text { senzorički } \\
\text { interes za } \\
\text { iggračku/osobu }\end{array}$ & 7 & 0 & 0 & 100 & 0 & 0 & 0,00 & 0,00 \\
\hline $\begin{array}{l}\text { Manirizmi } \\
\text { rukomi prstima i } \\
\text { drugi složeni } \\
\text { manirizmi }\end{array}$ & 7 & 0 & 0 & 100 & 0 & 0 & 0,00 & 0,00 \\
\hline Samoozljeđivanje & 7 & 0 & 0 & 100 & 0 & 0 & 0,00 & 0,00 \\
\hline $\begin{array}{l}\text { Pretjerani interes } \\
\text { za neobične ili } \\
\text { visokospecifične } \\
\text { teme }\end{array}$ & 7 & 0 & 0 & 100 & 0 & 0 & 0,00 & 0,00 \\
\hline $\begin{array}{l}\text { Kompulzivne ili } \\
\text { ritualne radnje }\end{array}$ & 7 & 0 & 0 & 100 & 0 & 0 & 0,00 & 0,00 \\
\hline
\end{tabular}

Legenda: $\mathrm{M}=$ središnja vrijednost; $\mathrm{SD}=$ standardna devijacija

S obzirom na to da su ograničeni i repetitivni obrasci ponašanja, interesa $i$ aktivnosti jedno od glavnih obilježja poremećaja iz spektra autizma, ovi rezultati jasno pokazuju kako se izostanak ili prisutnost stereotipnih obilježja može smatrati razlikovnim obilježjem selektivnog mutizma i poremećaja iz spektra autizma.

\section{Zajednička i razlikovna obilježja selektivnog mutizma i poremećaja iz spektra autizma}

Kao što je spomenuto, cilj ovoga rada bio je: opisati obilježja neverbalne komunikacije kod djece sa selektivnim mutizmom, ali i utvrditi koja su to zajednička i razlikovna obilježja selektivnog mutizma i poremećaja iz spektra autizma, kada se djeca nalaze u ispitnoj situaciji kako bi se dobile jasne smjernice, te pomoglo $u$ diferencijalnoj dijagnostici ova dva poremećaja. Kotrba (2014) u svojoj knjizi naglašava kako selektivni mutizam može biti pogrešno dijagnosticiran kao poremećaj iz spektra autizma budući da ponašanja i obilježja djece sa selektivnim mutizmom (slab kontakt očima, neutralan izraz lica, neuobičajen ili ukočen položaj tijela te izostanak govora) u situacijama izvan vlastitog doma mogu veoma nalikovati djeci s poremećajem iz spektra autizma. Hung i suradnici (2012) također upozoravaju kako obilježja djece sa selektivnim mutizmom, pogotovo izostanak socijalne interakcije s drugim ljudima, nalikuju obilježjima djece sa PSA-om te ostalim razvojnim teškoćama i kašnjenjima, stoga je nužno napraviti kvalitetnu i sveobuhvatnu procjenu kako bi se izbjegle pogrešne dijagnoze.

Istraživanje potvrđuje kako dio djevojčica dosljedno pokazuje neka obilježja koja nalikuju obilježjima djece sa PSA-om (minimalan kontakt očima, oskudni izrazi lica, rijetko započinjanje socijalnih interakcija i slično), ali i da 


\section{$0 \% 10 \% 20 \% 30 \% 40 \% 50 \% 60 \% 70 \% 80 \% 90 \% 100 \%$}

\begin{tabular}{|r|r|}
\hline Kontakt očima & \\
Izrazi lica upućeni ispitivaču & \\
Uporaba gesta & \\
\hline Dijeljenje uživanja u interakciji & \\
Kvaliteta započinjanja socijalnih interakcija & \\
Količina započinjanja socijalnih interakcija & \\
Kvaliteta socijalnih odgovora & \\
Količina recipročne socijalne komunikacije & \\
Cjelokupna kvaliteta uspostavljenog odnosa & \\
\hline Davanje informacija & \\
Traženje informacija & \\
Prepričavanje događaja & \\
Komentiranje tuđih emocija & \\
\hline Neuobičajeni senzorički interesi & \\
Manirizmi & \\
Samoozljeđivanje & \\
\hline Kompulzivne ili ritualne radnje & \\
\hline \hline
\end{tabular}

A.

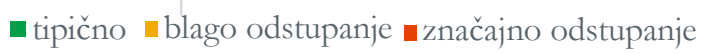

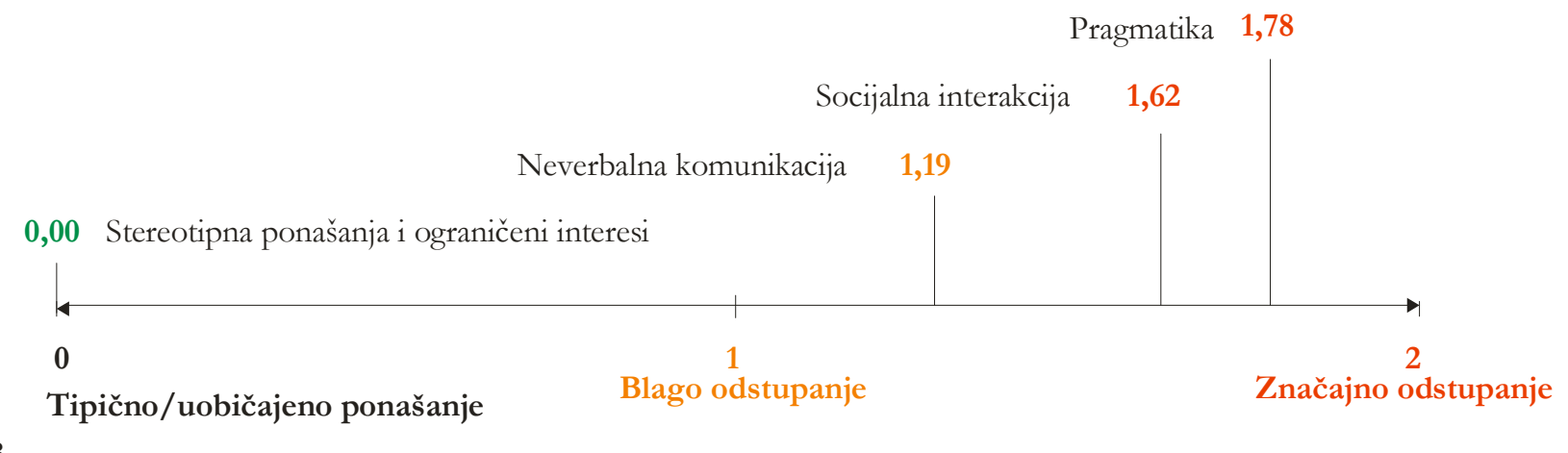

B.

Slika 1. Procjena obilježja spontanog ponašanja djece sa selektivnim mutizmom uporabom ADOS-a-2: A. Procjena pojedinih obilježja ponašanja u okviru neverbalne komunikacije, socijalne interakcije, pragmatičkih sposobnosti i stereotipnih ponašanja i ograničenih interesa; B. Prosječna ocjena pojedine skupine ponašanja na skali od 0 (tipično ponašanje) do 2 (značajno odstupanje).

postoje razlikovna obilježja (upotreba gesta, odsutnost eholalija te stereotipnih ponašanja i interesa) koja isključuju dijagnozu PSA.

Sveukupno, analizom prosječnih ocjena obilježja ponašanja u domeni neverbalne komunikacije, pragmatike, socijalne interakcije $\mathrm{i}$ stereotipnih ponašanja $\mathrm{i}$ ograničenih interesa (slika 1) lako se može zapaziti velik nesrazmjer u ocjenama stereotipnosti ponašanja i interesa (koji su u potpunosti procijenjeni tipičnima) i ocjenama koje opisuju obilježja interakcije i komunikacije koji su procijenjeni kao blago (neverbalna komunikacija) prema značajno (socijalna interakcija, pragmatika) odstupajućima. U nastavku slijedi opis pojedinih ponašanja.
Neverbalna komunikacija kod djece sa SM-om i djece sa PSA-om

Djeca s poremećajem iz spektra autizma često ne uspostavljaju kontakt očima za komunikacijske svrhe, te se odstupanja u kontaktu očima mogu primijetiti od najranije dobi (Werner i sur., 2005). U istraživanju je zabilježeno kako je $57,1 \%$ djevojčica sa selektivnim mutizmom u ispitnoj situaciji izbjegavalo te imalo minimalan kontakt očima. Osim toga, pokazano je i kako su djevojčice rjeđe uparivale kontakt očima s proizvodnjom gesta. S obzirom na to kako je čak 98,3\% ispitanika u istraživanju djece tipičnog razvoja (Kljunić i sur., 2016) imalo primjeren te socijalno usklađen kontakt očima, minimalan kontakt očima u ispitnoj situaciji 
u više od polovice sudionica sa selektivnim mutizmom može se smatrati obilježjem koje pomalo nalikuje djeci s poremećajem iz spektra autizma.

Manji broj te rjeđe korištenje gesta često su obilježje neverbalne komunikacije djece s poremećajem iz spektra autizma. Djevojčice sa selektivnim mutizmom u ovome su istraživanju spontano upotrebljavale konvencionalne, informativne $i$ instrumentalne geste, dok je zabilježena oskudna upotreba opisnih gesta. No, pri interpretaciji ovog ponašanja potreban je oprez budući da rezultati nekih istraživanja sugeriraju da oskudna pojava opisnih gesta može biti jedno od obilježja (ili specifikum) djece hrvatskoga govornog područja (vidi Kljunić i sur., 2016).

Djeca s poremećajem iz spektra autizma pokazuju odstupanja u izrazima lica koja su najčešće oskudna te kvalitativno drukčija (Grossman i sur., 2013). Istraživanje je pokazalo kako je većina djevojčica sa selektivnim mutizmom tijekom procjene izražavala emocije koje su upućivale na emocionalne krajnosti, a tijekom interakcija $s$ ispitivačem izraz lica djevojčica najčešće je bio neutralan. Oskudniji izrazi lica, osim što su pomalo nalikovali izrazima lica djece sa PSA-om, pridonijeli su i većoj neugodnosti tijekom ispitivanja.

\section{Socijalne interakcije djece sa SM-om i djece sa PSA-om}

Rijetko započinjanje te odgovaranje na interakcije koje su započele druge osobe, također su često viđeno obilježje osoba sa PSA-om. Recipročna socijalna interakcija djevojčica sa selektivnim mutizmom u ispitnoj situaciji značajno je nalikovala interakciji kakva se može vidjeti kod djece sa PSA-om. Djevojčice su rijetko započinjale interakcije s ispitivačem te se često nije mogla procijeniti kvaliteta započinjanja socijalnih interakcija. Većina interakcija djevojčica sa SM-om i ispitivača sastojala se od pitanja i odgovora, a djevojčice su najčešće minimalno ili uopće nisu reagirale na ispitivačeve pokušaje da ih uključi u interakciju.

\section{Pragmaticke sposobnosti djece sa SM-om i djece sa PS A-om}

Zbog smanjenog broja prilika kako bi razvila svoje socijalne vještine, djeca s poremećajem iz spektra autizma često imaju narušene pragmatičke sposobnosti. Pragmatičke vještine procijenjene protokolom ADOS-2 pokazale su kako su djevojčice sa selektivnim mutizmom vrlo rijetko iznosile informacije o svojim mislima, osjećajima $\mathrm{i}$ iskustvima te se raspitivale za ispitivačeve misli i osjećaje. Budući da većina djevojčica nije željela prepričati rutinski ili nerutinski događaj, teško se moglo procijeniti do koje je mjere dijete sposobno prepričati događaj na jasan i razumljiv način, pružajući dovoljno informacija te bez posebnih poticaja od ispitivača.

Budući da su i djevojčice sa SM-om i djeca tipičnog razvoja iz istraživanja Kljunić i sur. (2016) u ispitnoj situaciji pokazale odstupanja u pragmatičkim sposobnostima, rezultate ovoga istraživanja također treba interpretirati s oprezom.
Stereotipna $i$ ostala neuobičajena ponašanja djece sa SM-om i djece sa PSA-om

Stereotipna ponašanja i ograničeni interesi česti su kod djece s poremećajem iz spektra autizma. Sve djevojčice sa selektivnim mutizmom, međutim, postigle su kodove 0 na česticama: "Neobični senzorički interesi", "Manirizmi”, "Samoozljeđivanje", "Pretjerani interes za neobične ili visokospecifične teme ili predmete" te "Kompulzivne radnje", što znači da kod djevojčica nije bilo prisutno niti jedno ponašanje koje bi upućivalo na postojanje stereotipnosti ili neuobičajenih interesa.

\section{ZAKLJUČAK}

Cilj ovoga rada bio je: ispitati obilježja neverbalne komunikacije predškolske i školske djece sa selektivnim mutizmom, doznati koja su obilježja zajednička djeci sa selektivnim mutizmom i djeci s poremećajem iz spektra autizma u situacijama u kojima se očituje selektivni mutizam. Kao što je navedeno, djeca sa selektivnim mutizmom će ovisno o situaciji i osobama s kojima su u interakciji, upotrebljavati različite oblike verbalnog i neverbalnog izražavanja, odnosno, njihova je komunikacija pod snažnim utjecajem situacije/okolnosti u kojima se ona nalaze.

S obzirom na to da neverbalna komunikacija ima važnu ulogu za dijete sa selektivnim mutizmom, procjena neverbalnih sredstava koje dijete koristi u komunikaciji, načini na koje započinje interakcije s drugima, kao i reakcije djeteta kada ga se uključi u interakciju, mogu pomoći u dobivanju jasnije slike samoga poremećaja i utjecati na donošenje odluke o najprikladnijoj terapiji za dijete.

Rezultati istraživanja pokazuju da djeca sa selektivnim mutizmom u ispitnoj situaciji prikazuju niz neuobičajenih, odnosno odstupajućih ponašanja u obilježjima neverbalne komunikacije, socijalne interakcije i pragmatike. No, premda neka komunikacijska obilježja djece sa selektivnim mutizmom mogu nalikovati onima kod djece s poremećajem iz spektra autizma (oskudniji kontakt očima, snižena uporaba gesta, smanjeni raspon izraza lica, sniženo iniciranje i odgovaranje na socijalne interakcije, sužen raspon komunikacijskih funkcija i dr.,), njihovo se ponašanje jasno razlikuje od djece s poremećajem iz spektra autizma po nepostojanju stereotipnih ponašanja i neuobičajenih interesa (izostanak takozvanih B kriterija za dijagnozu poremećaja iz spektra autizma prema DSM-u-5). Dodatno, kod svih djevojčica sa selektivnim mutizmom je tijekom procjene uočena uporaba informativnih, instrumentalnih te konvencionalnih gesta, što je također potencijalni marker u diferencijalnoj dijagnostici, no njegovu pouzdanost je potrebno dodatno istražiti. Osim navedenih obilježja, u kliničkoj je praksi također važno provesti i detaljan intervju s roditeljima o obiteljskim odnosima te odnosima djeteta $i$ njegovih vršnjaka u školi ili vrtiću, jer će tek podaci o komunikacijskim obilježjima djeteta u različitim komunikacijskim situacijama omogućiti uvid u socijalno funkcioniranje djeteta sa selektivnim mutizmom.

Budući da se protokol ADOS-2 primjenjuje u dijagnostici poremećaja iz spektra autizma, izračunavanje sveukupnog rezultata (rezultat koji sadrži dio kodova iz područja komunikacije, recipročne socijalne interakcije te 
repetitivnih i stereotipnih ponašanja) omogućuje određivanje pokazuje li dijete $u$ ispitnoj situaciji ponašanja u zoni poremećaja iz spektra autizma ili ne. Važno je naglasiti da se ukupan rezultat čak pet djevojčica sa selektivnim mutizmom (od njih sedam) na protokolu ADOS-2 nalazio se u zoni poremećaja iz spektra autizma. To je dodatna potvrda važnosti kliničkog znanja i iskustva u interpretaciji rezultata različitih ljestvica, protokola i testova. Kotrba (2014), kao i autorice protokola ADOS-2, upozorava kako se protokol ADOS ne bi smio primjenjivati u procjeni djeteta sa selektivnim mutizmom jer vrlo lako može dovesti do pogrešnih zaključaka.

S obzirom na to da je u istraživanju sudjelovao vrlo mali i prigodan uzorak sudionika, nije moguća generalizacija dobivenih rezultata. Istraživanje s većim uzorkom sudionika, koji bi bili izjednačeni po spolu, kronološkoj dobi, dobi pojave selektivnog mutizma i drugim obilježjima, svakako bi dalo pravi uvid, ne samo u obilježja neverbalne komunikacije djece sa selektivnim mutizmom, već i u druga razvojna obilježja, te jasnije odredilo i definiralo specifičnosti komunikacijskih obilježja te djece.

\section{LITERATURA}

1) Američka psihijatrijska udruga (2014). Dijagnostički $i$ statisticki priručnik za duševne poreméaje, peto izdanje. Jastrebarsko: Naklada Slap.

2) Black, B., Uhde, T.W. (1995). Psychiatric characteristics of children with selective mutism: a pilot study. Journal of the American Academy of Child and Adolescent Psychiatry, 34(7), $847-$ 856.

3) Bork, P., Harwood, D. (2010). Transient $\neq$ persistent: determining the best approach to selective mutism intervention. The International Journal of Interdisciplinary Social Sciences, 5(3), 237-246.

4) Cline, T., Baldwin, S. (2004). Selective Mutism in Children: Second Edition. London: Whurr Publishers Ltd.

5) Ford, M.A., Sladeczek, I.E., Carlson, J., Kratochwill, T.R. (1998). Selective mutism: phenomenological characteristics. School Psychology Quarterly, 13(3), 192-227.

6) Gordon, I., Pierce, M.D., Bartlett, M.S., Tanaka, J.W. (2014). Training facial expression production in children on the autism spectrum. Journal of Autism and Developmental Disorders, 44(10), 2486-2498.

7) Grossman, R.B., Edelson, L.R., Tager-Flusberg, H. (2013). Emotional facial and vocal expressions during story retelling by children and adolescents with high-functioning autism. Journal of Speech, Language, and Hearing Research, 56(3), 1035-1044.

8) Gullberg, M., Holmqvist, K. (2006). What speakers do and what addressees look at: Visual attention to gestures in human interaction live and on video. Pragmatics \& Cognition, 14(1), 53-82.

9) Hung, S., Spencer, M.S., Dronamraju, R. (2012). Selective mutism: practice and intervention strategies for children. Children and Schools, 34(4), 222-230.

10) Kearney, C.A. (2010). Helping children with selective mutism and their parents: a guide for school-based professionals. Oxford: Oxford University Press.

11) Kearney, C.A., Vecchio, J.A. (2006). Functional analysis and treatment of selective mutism in children. The Journal of
Speech And Language Pathology, Applied Behavior Analysis, 1(2), 141-148.

12) Kearney, C.A., Vecchio, J.A. (2007). When a child won't speak. The Journal of Family Practice, 56(11), 917-921.

13) Kljunić, K., Cepanec, M., Šimleša, S. (2016). Imaju li hrvatska djeca urednog razvoja uistinu „urednu“ komunikaciju? Hrvatska revija za rehabilitacijska istraživanja, 52(2), 1-10.

14) Kolvin, I., Fundudis, T. (1981). Elective mute children: psychological development and background factors. Journal of Child Psychology and Psychiatry, 22(3), 219-232.

15) Kotrba, A. (2014). Selective Mutism: An Assessment and Intervention Guide for Therapists, Educators \& Parents. Eau Claire, WI: Pesi Publishing \& Media.

16) Kristensen, H. (2000). Selective mutism and comorbidity with developmental disorder/delay, anxiety disorder, and elimination disorder. Journal of the American Academy of Child and Adolescent Psychiatry, 39(2), 249-256.

17) Krysanski, V.L. (2003). A brief review of selective mutism literature. The Journal of Psychology, 137(1), 29-40.

18) Lord, C., Luyster, R., Gotham, K., Guthrie, W. (2017). Opservacijski protokol za dijagnostiku autizma. (urednice hrvatskog izdanja: M. Cepanec i S. Šimleša). Jastrebarsko: Naklada Slap.

19) Marc, R., Crundwell, A. (2006). Identifying and teaching children with selective mutism. Teaching Exceptional Children, 38(3), 48-54.

20) McInnes, A., Fung, D., Manassis, K., Fiksenbaum, L., Tannock, R. (2004). Barrative skills in children with selective mutism: an exploratory study. American Journal of SpeechLanguage Pathology, 13(4), 304-315.

21) Moldan, M.B. (2005). Selective mutism and selfregulation. Clinical Social Work Journal, 33(3), 291-307.

22) Mulligan, C.A., Hale, J.B., Shipon-Blum, E. (2015). Selective mutism: identification of subtypes and implications for treatment. Journal of Education and Human Development, 4(1), 79-96.

23) Nowakowski, M.E., Cunningham, C.C., McHolm, A.E., Evans, M.A., Edison, S., St. Pierre, J., Boyle, M.H., Schmidt, L. (2009). Language and academic abilities in children with selective mutism. Infant and Child Development, 18(3), 271-290.

24) Omdal, H., Galloway, D. (2008). Could selective mutism be re-conceptualised as a specific phobia of expressive speech? An exploratory post-hoc study. Child and Adolescent Mental Health, 13(2), 74-81.

25) Schwartz, R.H., Freedy, A.S., Sheridan, M.J. (2006). Selective mutism: are primary care physicians missing the silence? Clinical Pediatrics, 45(1), 43-48.

26) Vecchio, J.L., Kearney, C. (2007). Assessment and treatment of a Hispanic youth with selective mutism. Cinical Case Studies, 6(1), 34-43.

27) Werner, E., Dawson, G., Munson, J., Osterling, J. (2005). Variation in early developmental course in autism and its relation with behavioral outcome at 3-4 years of age. Journal of Autism and Developmental Disorders, 35(3), 337-350. 